\title{
CEP72 Gene
}

National Cancer Institute

\section{Source}

National Cancer Institute. CEP72 Gene. NCI Thesaurus. Code C122056.

This gene is involved in mitotic spindle formation. 